\title{
JUDICIALIZAÇÃO DA POLÍTICA E DEMOCRACIA - UMA ANÁLISE A PARTIR DE CHANTAL MOUFFE E MARK TUSHNET
}

\section{Daniel dos Santos Rodrigues*}

RESUMO. O artigo rediscute, a partir das teorias da hegemonia de Chantal Mouffe e dos diálogos institucionais de Mark Tushnet, os fenômenos da judicialização da política (o político invadindo "indevidamente" o jurídico) e do ativismo judicial (o jurídico invadindo "indevidamente" o político). Contesta a concepção usual de que o judiciário teria a "última palavra" na interpretação jurídica e defende uma maior proteção da democracia, pois é esta, não o judiciário, que, em última instância, protege os direitos. Conclui-se que, para sua maior legitimidade e eficiência, deve então o Poder Judiciário receber novos influxos democráticos e estar sujeito a maior accountability.

Palavras-chave: Judicialização da política; Democracia; Separação dos Poderes; Soberania; Diálogos Institucionais.

\section{JUDICIALIZATION OF POLITICS AND DEMOCRACY - AN ANALYSIS FROM CHANTAL MOUFFE AND MARK TUSHNET}

\begin{abstract}
This paper reassesses, taking account the theories of Chantal Mouffe's hegemony and of Mark Tushnet's institutional dialogues, the phenomena of the judicialization of politics (the political invading "unduly" the justice) and of judicial activism (the justice invading "unduly" the political). It contests the conception that the Judiciary has the "last word" in law interpretation and defends a greater protection of democracy, since it is this, not the Judiciary, that, in the end, protects rights. It is concluded that for its greater legitimacy and efficiency, the Judiciary should receive new democratic inflows and be subject to greater accountability.
\end{abstract}

\footnotetext{
* Mestre em Direitos Humanos pela Universidade Federal de Goiás. Doutorando em Direito na Universidade Federal de Minas Gerais. Promotor de Justiça do Ministério Público do Estado de Minas Gerais. E-mail: danielsrodrigues@live.com. Endereço: SQN 212 bl. B ap. 309, Brasília-DF, CEP 70864-020.
} 
Key-words: Judicialization of politics; Democracy; Separation of Powers Sovereignty; Institutional Dialogues.

\section{Introdução}

O presente artigo tem como objetivo rediscutir o local atual da democracia por meio de um olhar não usual sobre o fenômeno atual da judicialização da política (o político invadindo "indevidamente" o jurídico) ou, o reverso da mesma moeda, do ativismo judicial (o jurídico invadindo "indevidamente" o político).

As análises comumente feitas acerca do assunto, tanto à esquerda quanto à direita, acabam por se valer de pressupostos datados e/ou ingênuos, ora ignorando a história do ideal do Estado democrático-liberal forjado no século XVIII, que não se resumia ao seu aspecto puramente jurídico-técnico e que reconhecia a soberania quando o povo se movimenta sem qualquer concessão do Estado ou do Direito, ora ignorando ou negando a impossibilidade de o direito contemporâneo validar, definitivamente, algum critério de "verdade" ou de "segurança jurídica", o que não passa de uma ingenuidade racionalista jurídico dos primórdios do Iluminismo.

Por tais motivos, o presente artigo, desvelando a tentativa frequente de esvaziamento da democracia no sentido de se permitir que ela só se realize por meio de uma outorga por parte do Direito (a juridificação da política), tem como objetivo demonstrar que, para um melhor funcionamento do próprio sistema democrático, há que se aceitar e regular (e não negar ou impedir) a atividade política do Poder Judiciário.

Para o encaminhamento dessa discussão, dividimos o texto em duas partes. $\mathrm{Na}$ primeira, avaliar-se-á, a partir do exemplo da Operação Lava Jato, a dificuldade de se adotar uma postura jurisdicional puramente técnica em vista da inexorabilidade da política e do caráter paradoxal da democracia. Na segunda parte, considerando a impossibilidade da separação total entre direito e política, aprofundaremos o debate em torno da judicialização da política (ou do ativismo judicial).

Faremos tal percurso procurando demonstrar, em um primeiro momento, como a política - isto é, a dicotomia 'amigo-inimigo', antítese segundo a qual todos os agrupamentos humanos se arranjam por meios de atos de exclusão e identidade - é inescapável e que, por tal razão, nunca poderá ser anulada pela ciência ou pela técnica jurídicas. Após, salientaremos que 
a democracia, por possuir como marca a contestação permanentemente de qualquer certeza, extrai sua força justamente da própria impossibilidade de reconciliação última entre os princípios liberais (liberdade) e democráticos (igualdade), impedindo seu fechamento ou a sua dissolução por completo. Por tais motivos, concluiremos que a insistência de boa parte dos atores jurisdicionais atuais em tentar separar de forma estanque direito e política, ao invés de proteger a democracia, acaba por enfraquecê-la, pois, ao ignorar os dissensos, promovem a politização excessiva da vida social e a retroalimentação violenta dos conflitos latentes na sociedade.

Na sequência, será visto como a questão acerca da judicialização da política (ou do ativismo judicial) no Brasil é mal formulada, uma vez que ignora que o principal problema de nossa atividade jurisdicional está em outro lugar: na assunção de uma forma de separação dos poderes que reserva a política somente ao poder legislativo (e também ao executivo, se considerarmos um sistema presidencialista). Tal fato faz com que o Poder Judiciário seja infenso ao controle democrático e atue dentro de "zonas de autarquia", nas quais decisões são tomadas sem justificação ou fundamentação suficiente e de forma arbitrária. Daí que se faz importante a adoção de um novo modelo de racionalidade jurídica, qual seja, um que admita e internalize a impossibilidade de o direito contemporâneo validar, definitivamente, algum critério de "verdade" ou de "segurança jurídica".

Em seguida, demonstraremos que, para a construção deste novo modelo de racionalidade jurídica, há que se compreender que os consensos (sempre provisórios) são produzidos por meio de articulações hegemônicas de poder, que conflitam e se impõem a diferentes posições de influência e mobilização. Deste modo, revela-se primordial a proteção não do direito pura e simplesmente, mas da atividade político-democrática (a possibilidade de construção de diferentes posições hegemônicas), pois é esta (não a Constituição ou o Poder Judiciário) que, em última instância, protege os direitos.

Por fim, agora com a valia das teorias dos 'diálogos institucionais', contestaremos especialmente o pressuposto tradicional que sustenta que o Poder Judiciário teria a "última palavra" sobre o direito. Demonstrando que a interpretação constitucional e legal nunca tem fim, pois ocorre em ciclos que se reiniciam indefinidamente, por meio de diálogos com os demais poderes e com a sociedade até a formação de consensos político-jurídicos, concluiremos que se faz premente submeter a atividade jurisdicional a uma maior accountability democrática, apresentando alguns caminhos a serem perseguidos para tal desiderato. 


\section{Do moralismo ao populismo jurídico-midiático}

A análise de um importante fato da história recente do Brasil - a chamada Operação Lava Jato - mostra-se particularmente útil para exemplificarmos as dificuldades de insistirmos em uma atividade jurisdicional puramente técnica, na qual o juiz não seria nada além do que a "boca da lei" e estaria impedido de atuar politicamente.

Começamos tal análise tendo como mote o artigo escrito por Margarida Maria Lacombe Camargo e José Ribas Vieira (2016) intitulado A estratégia institucional do juiz Sergio Moro descrita por ele mesmo, o qual faz interessante análise da judicialização da política a partir de uma leitura da Operação Lava Jato, leitura esta feita por meio do cotejo entre as ideias acadêmicas e a atuação profissional de Moro.

Em termos gerais, Camargo e Vieira destacam, a partir da leitura de duas obras do juiz federal Sergio Moro - o livro de 1998 Legislação suspeita? Afastamento da presunção de constitucionalidade da lei e o artigo de 2004 Considerações sobre a Operação Mani Pulite (mãos limpas) - , o ativismo do magistrado em vista de sua defesa de uma certa superioridade moral do Poder Judiciário. Segundo os autores, referindo-se à concepção de democracia homogênea de Carl Schmitt, o Poder Judiciário, encarnado na figura de Sergio Moro, estaria buscando (consciente ou inconscientemente) a aclamação popular, prescindindo de qualquer elemento eletivo e promovendo um estado de exceção, no qual os súditos (o povo brasileiro) aclamaria o soberano - isto é, o próprio magistrado, por meio de uma perfeita identificação dos primeiros com o último. Ao cabo, tal protagonismo judicial, conforme os autores, representaria o deslocamento da libido social do Executivo para o Poder Judiciário.

Tal texto nos fornece valorosos insights com o sentido de aprofundar o debate acerca do ativismo judicial e da crescente moralização do Direito, por meio de um enfrentamento mais incisivo do que de fato entendemos por política, democracia e soberania. Em suma, considerando a plausibilidade dos argumentos de Camargo e Vieira, é possível divisar no pensamento e na conduta de Sergio Moro uma contradição insolúvel entre a defesa de uma proeminência do Poder Judiciário, baseado numa concepção liberal do Estado de Direito inspirada em Dworkin, com um ativismo político de matiz supostamente schmittiano, buscando refundar o Direito a partir da criação e posterior resolução do estado de exceção. Como resolver esse impasse? 
Analisando a obra de Moro de 1998, Camargo e Vieira argumentam que o magistrado, nesta época, já defendia certa superioridade do Poder Judiciário frente aos demais poderes com relação à interpretação das normas constitucionais, as quais deveriam ser submetidas a severo exame por parte dos juízes. No texto de 2004 do magistrado, vemos a continuação da defesa de um protagonismo judicial, mas agora "[...] sob um viés mais corporativo e com poder de articulação política" (CARMARGO; VIEIRA, 2016).

O texto de 2004 é uma espécie de roteiro fiel do que viria a ser a Operação Lava Jato. No artigo, Moro (2004, p. 59-61) sustenta o uso das delações premiadas por ocasião das prisões preventivas (fundamentadas em razões concretas, ressalta) e o vazamento de informações para se desgastar o poder político, arrebatando a "opinião pública" para a defesa "democrática" das investigações.

Lendo o que escrevera o magistrado em 2004, fica claro que sua decisão de tornar públicos os áudios do ex-presidente Luiz Inácio Lula da Silva com a ex-presidente Dilma Rousseff, por exemplo, não foi um ato jurídico puro e simples, mas um calculado ato político (BARROS, 2018), justamente com a intenção de constranger os demais poderes e as cortes superiores (talvez não apenas elas). Moro estava certo em desconfiar dessas cortes (em um país definido por sua brutal desigualdade social, "foro privilegiado" e nomeações políticas para tais Tribunais é uma fórmula perfeita para a manutenção das estruturas viciadas do poder), no entanto se equivoca ao achar que o arbítrio pré-liberal de nossa toga poderia ser substituído pela "iluminação" de um direito supostamente liberal-formal-racionalista-imparcial que, ao cabo, acentua os conflitos por negar a própria essência da política democrática. Vejamos.

Tal equívoco já de início se revela quando percebemos que os mesmos erros cometidos na Mani Pulite parecem se repetir na Lava Jato, uma vez que Moro trata quase como sinônimos categorias complexas e sabidamente problemáticas como 'povo' e ‘opinião pública' ${ }^{1}$.

Muito embora se ensaie uma ressalva ("a ação judicial não pode substituir a democracia” (MORO, 2004, P. 61)), vemos aqui, então, - e este é o ponto fulcral da presente investigação - sérios equívocos acerca da própria concepção do 'político' e do 'ideal democrático', questões que só podem ser devidamente compreendidas se retomarmos os ideais metafísicos do Iluminismo e do nascimento do direito moderno.

A ciência moderna nasce com o nominalismo de Ockham, o que abriu caminho para o método cartesiano e para a filosofia política de Maquiavel e de Hobbes, fundando não apenas

${ }^{1}$ É comum no Brasil se achar que a “opinião publicada” é opinião pública. 
o liberalismo político, mas o positivismo jurídico e a própria ideia de política como ciência e como técnica (RODRIGUES, 2014, p. 39-60).

É o próprio Schmitt que nos elucida esse aspecto dominante desde então da ciência política moderna, ao constatar a aversão à política por parte de muitos liberais. Conforme Schmitt, o pensamento liberal não possuiria uma verdadeira teoria política, mas somente uma crítica à política, uma vez que tenderia a negar a verdadeira essência do político, qual seja, a inexorável dicotomia 'amigo-inimigo', antítese segundo a qual todos os agrupamentos humanos se arranjam por meios de atos de exclusão e identidade e que também representa o mais extremo grau de intensidade de uma união ou uma separação antes da guerra (2007, pos. 870-976).

Para Schmitt, a aludida negação do político advém do individualismo, o qual tem como inclinação desconfiar de toda e qualquer instituição que restrinja a liberdade individual. Segundo Schmitt, essa desconfiança se transformava em pavor diante da possibilidade de dominação da burguesia pela massa inculta, isto é, o medo da própria democracia (1986, p. 13; 1996, p. 20-1) $)^{2}$.

No entanto, ao final, o pretenso decisionismo de Schmitt não foi capaz de resolver a relação instável entre liberalismo e democracia e com os dilemas da secularização, de maneira que seu pensamento sacrificou o primeiro (liberalismo) em nome da segunda (democracia), nos termos homogêneos e substantivos que defendia: só haveria democracia quando o povo, como um grupo homogêneo e substantivo, se identifica perfeitamente com o soberano.

Facilmente se vê que essa solução schmittiana, muito embora apresente um correto entendimento do político, falha em compreender o fenômeno democrático moderno, porquanto elimina quase que por completo o pluralismo e o papel emancipatório do sujeito de direito liberal, aproximando a democracia de uma ditadura.

A chave para a solução de tal impasse é fornecida pela concepção de 'política agonística' ou de 'democracia radical' da filósofa política belga Chantal Mouffe. De matiz marxista, Mouffe acertadamente vem a termo com o pluralismo e com as instituições liberaldemocráticas, negando o determinismo do materialismo histórico-científico marxista e

\footnotetext{
${ }^{2}$ Registre-se que a constante das resistências diversas à democracia sempre foi o argumento de que o povo, ignorante, não sabe decidir por si mesmo, concepção típica do liberalismo dos séculos XVIII-XIX (BERCOVICI, 2013; HOBSBAWM, 2002, p. 128; LYNCH, 2014, p. 21-40).
} 
afirmando que a maior marca da modernidade é a democracia, mormente sua capacidade de dissolver certezas e de nos permitir visualizar que o social é sempre indecidível e contingente.

Seguindo em parte o conceito do político formulado por Schmitt, Mouffe procura demonstrar que o conflito, ao contrário do consenso, é tanto central como fundamental no contexto das democracias modernas e não pode nunca ser eliminado. No entanto, sua visão da distinção 'amigo-inimigo' schmttiana é atenuada e traduzida por uma antítese entre adversários (e não inimigos) políticos, os quais devem se respeitar, pois o Outro (o adversário) é fundamental para a construção da identidade do próprio Eu (o aliado) e para a manutenção da possibilidade de construção de novos consensos, novas identidades e novas universalidades se o adversário é eliminado, não há possibilidade de democracia. O fio condutor de sua tese é demonstrar que a insistência liberal na necessidade de consensos a todo custo mascara e torna invisíveis os conflitos reais existentes no seio das sociedades e, por consequência, não distingue posições políticas. O resultado dessa indistinção é a morte da política democrática, o que pode semear a demagogia e o populismo, hábeis em manipularem identidades fundamentalistas de todos os tipos (MOUFFE, 1996, p. 11-7).

Daí que vai explicar Mouffe (1996, p. 22-4) que é a democracia a marca das sociedades modernas, uma vez que o princípio democrático inaugura, a partir da emancipação do indivíduo, uma contestação permanente e irreversível do poder, da lei e do conhecimento, tornando o social sempre indecidível e promovendo a dissolução contínua de certezas ${ }^{3}$. Exatamente por tal motivo sua natureza é intrinsecamente paradoxal, extraindo sua força na própria impossibilidade de reconciliação última entre os princípios liberais (liberdade) e democráticos (igualdade). Conforme escreve Mouffe, a política liberal-democrática só pode ser visualizada de fato como um paradoxo, pois tanto a liberdade quanto a igualdade perfeitas são irrealizáveis e impossíveis ${ }^{4}$; visualizá-la como um paradoxo impede de fechá-la ou dissolvê-la por completo, sendo tal circunstância a própria condição de possibilidade "[...] for a pluralist form of human coexistence in which rights can exist and be exercised, in which freedom and equality can somehow manage to coexist" $\left(2009\right.$, p. 10-11) ${ }^{5}$.

\footnotetext{
${ }^{3}$ Importante aqui destacarmos a importância da 'incerteza' para a democracia, como registra também Shapiro (2006, p. 274).

${ }^{4}$ Esse paradoxo é análogo à "terceira antinomia das idéias transcendentais" de Kant (1989, p. 406-7).

5 “[...] para uma forma pluralista de existência humana na qual os direitos podem existir e serem exercidos, na qual liberdade e igualdade podem de algum modo coexistir" (tradução nossa). Interessante acrescentar que Mouffe (2009, p. 10) descreve que a relação entre os valores liberais e democráticos não é de 'negociação', mas de 'contaminação', no sentido de que uma vez efetuada a articulação entre esses dois valores, mesmo que de forma precária, cada um deles acaba por mudar a identidade do outro.
} 
A total incompreensão atual desta relação dinâmica, instável e positiva entre liberalismo (Estado de Direito, direitos humanos e separação dos poderes) e democracia (soberania popular e igualdade) é dominante nos nossos círculos jurídicos, sejam no Brasil ou no exterior, uma vez que há uma redução da democracia à constituição dos próprios direitos, transformando toda em qualquer reivindicação democrática em uma mera concessão do aparato jurídico (juridificação da política), o que contraria a própria ideia do Estado democrático-liberal forjado no século XVIII por Hobbes, Rousseau, Sieyès, Locke e Kant (MAUS, 2010, p. 13352), e que não se resumia ao seu aspecto puramente jurídico-técnico, como supunha Schmitt. E isto porque a soberania só existe quando existem "âmbitos isentos do Direito", nos quais o povo se movimenta sem qualquer concessão do Estado, o que garante a própria modificação e o aperfeiçoamento democráticos das leis (MAUS, 2010, p. 140).

O desvio desse caminho do pensamento político liberal de suas origens talvez deite razão nos vários usos classistas do liberalismo e do paradigma científico (MATTEUCCI, 2004, p. 699-700; SOUZA, 2015, p. 90), os quais ainda não ensejaram a eliminação por completo do racionalismo pretensamente infalível dos primórdios do Iluminismo (LATOUR, 1994; SHAPIRO, 2006, p. 266-8). Daí a ambiguidade de muitos dos juristas liberais atuais, ora se vinculando a um positivismo deformado ora a um truísmo de um direito natural que não poderíamos dizer nem pré nem moderno.

Por tal razão é que podemos visualizar facilmente hoje a disseminação de um sentimento explícito de ódio à política, quando sem dificuldade são confundidos, como visto acima, conceitos como os de 'democracia' e ‘opinião pública', 'político’ e 'partidarismo', nem tanto pela falta de política, mas pela politização excessiva da vida social, levada a cabo pela negação do dissenso, o que, ao invés de resolvê-los, faz com que surjam cada vez mais violentos, o que é terreno fértil para os demagogos. Daí que o judiciário, na tentativa de ser um aparato técnico impessoal de sublimação do conflito através de fórmulas racionalistas, acaba por funcionar não para proteger a higidez do Estado, o equilíbrio dos poderes e a produção espontânea da política por cidadãos livres, mas justamente para o contrário, exercendo um jogo de deslegitimação democrática contínuo e temerário. Em suma, negar o político não ajuda a autonomia do direito; ao revés, tal negação, ao ignorar as relações positivas e necessárias entre direito e política, acaba por implodir a capacidade do jurídico de encontrar decisões minimamente consensuais e legítimas, já que a busca pela 'imparcialidade' se revela sempre um trabalho penoso e inútil. 
Não é segredo que o ativismo judicial independe do matiz ideológico, assim como o apelo a categorias metafísicas e suprapositivas para a eliminação da conflituosidade social. Porém a Constituição de 1988, apesar de ser em muitos aspectos uma colcha de retalhos, permitiu (ao menos por algum tempo) a produção de consenso mínimos, em bases democráticas, liberais e sociais, com relação a aspectos essenciais da fundação do país.

Daí que a Constituição de 1988 permitiu que muitos juízes pudessem ser Moro (ao menos no que tange ao fim de se fazer valer os direitos e objetivos fundamentais constitucionais, não com relação a alguns dos questionáveis métodos que empregou para tal desiderato) e não o foram, e é curioso notar que muitos dos magistrados que hoje celebram o juiz de Curitiba são, em razoável escala, os mesmos que desde sempre vêm negando eficácia aos direitos fundamentais, apelando, por exemplo, para o uso de fórmulas genéricas como "reserva do possível", "discricionariedade administrativa", "separação dos poderes", sem a devida análise concreta dos casos em tela e mesmo contrariando descrições normativas detalhadas acerca de políticas públicas diversas relacionadas aos direitos sociais (GOUVÊA, 2003; RODRIGUES, 2008). Em suma, aqui a ambiguidade também se revela no casuísmo falsamente apolítico de certos ativismos.

Então não é por acaso que as promessas não cumpridas da Constituição deságuam facilmente em frustração, recalque e, por fim, em demagogia. É nesse momento que as consequências são confundidas com suas causas, abrindo espaço para o questionamento leviano do próprio texto constitucional, tantas vezes vilipendiado e distorcido e agora, moribundo, fortemente acusado de ser o seu próprio algoz.

A atual moralização do Direito, promovida por Sergio Moro e por tantos outros juízes, promotores, procuradores, advogados e profissionais do Direito se faz como resultado de todos esses equívocos, alguns profundamente conscientes de tais paradigmas, muitos outros tais como Eichmann, o burocrata alemão símbolo da banalidade do mal do regime nazista.

Exatamente por isso é que o texto de Ingerbor Maus, citado por Lacombe Camargo e Ribas Vieira, faz-se conclusivo e lapidar. Discorrendo sobre o apoio incondicional dos magistrados alemães ao novel regime nazista em 1933, Maus faz um relato sintomático e surpreendentemente atual sobre o quão fácil a independência funcional, a moralização do direito e uma pretensa "vinculação estrita à lei” (própria das superadas escolas exegéticas, utilizadas como disfarce e fetiche para o corporativismo) podem se degenerar no mais rasteiro antipositivismo, tudo, é claro, em nome dos bons costumes e do combate à corrupção: 
As reivindicações dirigidas ao Judiciário no sistema nazista conectamse imediatamente ao autoentendimento que a justiça desenvolveu antes de 1933. A própria acumulação, no direito nazista, de fórmulas ligadas à comunidade e ao bem-estar comum que permitem, conforme a necessidade, desconsiderar dispositivos jurídicos individuais em prol de finalidades comunitárias "superiores" já é a expressão da ideologia de que o povo alemão formaria, no nacional-socialismo, uma nação em que as antigas clivagens sociais e os antigos conflitos entre grupos estariam abolidos. Foi também nesse sentido que se expressou uma autêntica autoconsciência da justiça alemã quando, já em 19 de março de 1933, em uma declaração da direção da Associação dos Juízes alemães, que depositava "total confiança" em Hitler, formulou-se: "O juiz alemão sempre foi nacionalista e consciente de sua responsabilidade (...) ele julgou apenas segundo a lei e (!) a consciência (!). (...) Possa a grande obra da construção do Estado dar logo ao povo alemão o sentimento de pertença incondicional”. (MAUS, 2010, p. 32)

Assim, nesta quadra história, fica claro que um decisionismo judiciário proto-populista também não nos salva ${ }^{6}$. Nada indica que o país saia melhor do que entrou após esta tempestade perfeita. Tudo vai depender de como os atores que hoje formam essa nova identidade/representação nacional, como os soberanos que decidem sobre o caso de exceção, vão agir daqui por diante. Se constituírem essa nova identidade também considerando aquilo que hoje excluem (o 'outro constitutivo' de Derrida), podemos ter um Estado que consiga equilibrar, apesar das intrínsecas tensões, as tradições liberais e democráticas.

\section{A necessidade de se desjuridificar (relativamente) a democracia (ou de quem é a soberania?)}

Como exposto acima, o impasse em torno de uma possível separação entre direito e política tem como consequência inevitável a moralização de ambos, uma vez que o pensamento jurídico hegemônico atual insiste na fé ao racionalismo iluminista dos seus primórdios e em

\footnotetext{
${ }^{6}$ Apesar de que, ironicamente e no fundo, Schmitt não era um decisionista, assim como não demonstram ser os protagonistas da Operação Lava Jato. Cf. SCHMITT, 1998.
} 
suas doutrinas do meliorismo (o mito do progresso sem fim da humanidade) e da infalibilidade da razão humana (DOUZINAS, 2010, p. 83; GRAY, 1995, p. 19; SHAPIRO, 2006, p. 266-8). Assim, bem se vê que tal dificuldade não pode ser resolvida com a expulsão da política do e pelo direito, tampouco com uma mistura dos dois de maneira insidiosa ou sem qualquer tipo de filtro ou controle. Para entendermos como resolver essa questão, há primeiro que apontarmos os equívocos do problema em torno da judicialização da política, tema bem construído por José Rodrigo Rodriguez.

Pois bem. Para Rodriguez (2013, p. 183), no fundo, a questão da judicialização da política só possui algum sentido quando pensamos como “[...] padrão uma teoria normativa da política que se apoia em uma concepção bastante particular da separação dos poderes”. Isto é, a judicialização da política (o político invadindo "indevidamente" o jurídico) ou, o reverso da mesma moeda, o ativismo judicial (o jurídico invadindo “indevidamente” o político), são dificuldades que se apresentam de maneira mais aguda em modelos político-normativos nos quais a forma de separação dos poderes reserva a política somente ao poder legislativo (e também ao executivo, se considerarmos um sistema presidencialista), cabendo ao judiciário apenas a tarefa de aplicação "técnica" da lei. Neste sentido, o desvelamento de tal doutrina político-normativa da separação dos poderes teria a função de demonstrar que uma outra doutrina poderia ser construída, na qual se permita ao judiciário fazer política ${ }^{7}$.

Neste ponto, porém, avulta-se a necessidade de nos conformarmos com uma verdade simples e peremptória: a impossibilidade de o direito contemporâneo validar, definitivamente, algum critério de "verdade" ou de "segurança jurídica" (como o de sustentar a existência de apenas uma única decisão correta para o caso concreto). Daí que a tentativa de "[...] suprimir a instabilidade [jurídica], no mundo atual, não passa de uma ilusão bem intencionada ou com pretensões autoritárias" (RODRIGUEZ, 2013, p. 167).

Em razão desse panorama problemático, Rodriguez (2013, p. 150-64), apesar de ser mais descritivo do que propositivo em sua obra, esboça algumas saídas para uma reformulação do nosso sistema jurisdicional, basicamente refletindo sobre dois possíveis âmbitos de controle das decisões: 1) por meio de novos desenhos ou constrangimentos institucionais; 2) e por meio

\footnotetext{
7 Segundo aponta Rodriguez (2013, p. 185), o sentido de $O$ espírito das leis de Montesquieu nunca foi o de separar os "poderes" de forma estanque, mas sim de impedir a constituição de poderes absolutos, sobre os quais não fosse possível exercer qualquer controle. Lendo Montesquieu, no entanto, essa afirmação de Rodriguez é parcialmente correta, como se verá à frente.
} 
de um novo modelo de racionalidade jurídica, que deveria ser padronizado e adotado em vários níveis. Fixemo-nos, de início, no segundo âmbito, deixando o primeiro mais à frente.

Para Rodriguez a padronização do modelo de racionalidade jurídica, em todos os níveis possíveis - didático, operacional, seletivo, descritivo, normativo e legitimador -, teria a função, por evidente, de trazer segurança ao sistema jurídico. No entanto, admite o autor que tal empreendimento teria custos bem elevados, sem contar que sempre esbarraria na rivalidade com outros modelos de racionalidade (RODRIGUEZ, 2013, p. 163-4). Nada obstante, não há como descartar totalmente a proposta. Muito embora não possua uma maior compreensão de que é justamente a política democrática o elemento provocador da insegurança jurídica, a proposição, de alguma forma, tangencia a questão fulcral acerca da necessidade de certa estabilidade (mesmo que momentânea) do sistema. Daí a pergunta fundamental: como construir consensos provisórios e estabilidade em uma democracia plural sem se recorrer a expedientes autoritários?

Primordialmente, faz-se imprescindível lidarmos com a natureza paradoxal da democracia de outra forma: ao invés de a negarmos, melhor sabermos lidar com ela. Daí que o conceito de hegemonia de Mouffe e Ernesto Laclau, desenvolvido em 1985 na obra conjunta Hegemony and Socialist Strategy - Towards a Radical Democratic Politics, se faz útil aqui, pois nos fornece subsídios para compreender como, em um ambiente de 'democracia radical', o consenso (provisório, diga-se) só pode ser alcançado a partir de uma articulação hegemônica de poder, que conflita e se impõe a diferentes posições de influência e mobilização.

Em razão da indecidibilidade do social, Mouffe e Laclau lançam mão do conceito de hegemonia de Gramsci e de uma teoria do discurso (discursividade), as quais reconhecem que qualquer ordem política só pode existir por meio de uma articulação hegemônica discursiva, que estrutura diferentes posições de sujeito particulares em uma cadeia de equivalência para assim construir - rivalizando com diferentes posições antagônicas - uma universalidade. Nesses termos, portanto, considerando que uma universalidade política só se constitui dentro de uma sociedade por meio de disputas contra diferentes posições antagônicas, o político tem o status de 'ontologia do social'. Assim, nas palavras de Mouffe e Laclau '[...] it is vital for democratic politics to acknowledge that any form of consensus is the result of a hegemonic 
articulation, and that it always has an 'outside' that impedes its full realization" (2014, p. xviii) ${ }^{8}$.

Com efeito, parece ser impossível, nem mesmo desejável, impedir o judiciário de fazer política. Ora, sendo a imparcialidade uma quimera, e o é certamente, devemos que admitir o papel político do judiciário, que não pode ser visualizado como algo temerário.

Não que se permita com isso uma função semelhante ao da atuação política do Legislativo ou do Executivo, mas em uma medida que permita o controle social e submeta as decisões judiciais a maior escrutínio público ${ }^{9}$, visualizando-se também o juízo não apenas como uma arena de embate entre forças políticas externas que buscam posições de poder hegemônicas, mas também como um agente político legítimo.

Peguemos a democracia estadunidense como exemplo - apesar de ela não fugir, no geral, das dificuldades semelhantes que enfrentamos em torno da questão: a forma como enxergam a política nos tribunais é mais pragmática e menos moralista e ingênua do que a nossa. O jurista estadunidense Mark Tushnet (2010) faz um balanço interessante não só da importância política da Constituição dos EUA, mas também do funcionamento político da Suprema Corte e das abertas inclinações ideológicas de seus juízes, muitos dos quais exerceram carreira política no Legislativo e no Executivo, filiados aos partidos Republicano ou Democrata. A explicação que o autor fornece para essa relação mais aberta entre direito e política nos EUA é, basicamente, a desregulamentação 'relativa' do sistema político-partidárioeleitoral americano, que permitiu a movimentação política sem grandes amarras jurídicas e a criação de um sistema bipartidário (dentro de um modelo distrital) que descomplexifica a governabilidade, diferentemente da miríade de partidos no Brasi ${ }^{10}$. Daí que os movimentos históricos de interpretação da Constituição americana vinculam-se muito mais à força política e liderança dos presidentes americanos e das ideias e regimes que defendem do que de movimentos autônomos da Suprema Corte (TUSHNET, 2010, p. 116-7).

Exatamente em vista disso é que o Tushnet vai escrever, corretamente, contrariando o senso comum dos constitucionalismos moderno e contemporâneo, que a Constituição não tem

\footnotetext{
8 “[...] é vital para a política democrática reconhecer que qualquer forma de consenso é o resultado de uma articulação hegemônica e que sempre existe uma 'parte exterior' que impede sua total realização" (tradução nossa).

${ }^{9}$ Aqui se faz importante impedir as "zonas de autarquia", os espaços nos quais as decisões judiciais são tomadas sem justificação suficiente e/ou de forma arbitrária (RODRIGUEZ, 2013, p. 171).

${ }^{10}$ Não se olvida aqui o problema da sub-representação (de minorias e de ideologias) como consequência de um modelo eleitoral distrital e das críticas existentes ao 'duopólio' exercido pelos Partidos Democrata e Republicano (SHAPIRO, 2006, p. 262-3).
} 
como objetivo imediato a proteção dos direitos fundamentais, mas sim a proteção da política, pois é esta quem protege, ao cabo, os direitos: "The Constitution matters because it provides a structure for our politics. It's politics, not "the Constitution," that is the ultimate - and sometimes the proximate - source for whatever protection we have for our fundamental rights" (TUSHNET, 2010, p. 1) ${ }^{11}$.

Evidentemente uma Constituição pode insistir em um modelo de separação dos poderes na qual o fazer político fique restrito ao Poder Legislativo (e também ao Executivo). Maus (2010, p. 215-34), por exemplo, segue este entendimento, defendendo que, independentemente dos modelos clássicos de separação dos poderes que se escolha - o parlamentarista-democrático (de Locke, Kant e Rousseau, no qual a soberania é indivisível, sendo monopólio do povo, por meio do parlamento) ou o presidencialista (monárquicoconstitucional, com origem em Montesquieu, na qual a soberania é dividida em termos funcionais tão somente entre Legislativo e Executivo, sendo este último uma espécie de "legislador negativo", por meio do direito ao veto) - , a função legislativa, isto é, a soberania, nunca poderia ser exercida pelo Poder Judiciário. Mas há que se reconhecer as dificuldades de tal desenho após a desconstrução do racionalismo iluminista empreendida pela política democrática, com seu potencial de dissolver certezas, como vimos acima. Assim, a questão torna-se, então, encontrarmos alguma forma de ampliar a democratização do próprio poder judiciário (isto é, promover a eliminação ou a mitigação das “zonas de autarquia”) e/ou fortalecer o papel do parlamento (desjuridificando relativamente a democracia), já que contrariar o papel político no ato de se interpretar o direito demonstra ser um trabalho inútil e contraproducente.

Neste último aspecto cabe uma consideração importante. Muito embora o modelo de Montesquieu relegue ao poder judiciário a um papel funcional diferente (a sua célebre frase de que "[...] os juízes [...] são apenas [...] a boca que pronuncia as palavras da lei” (2000, p. 175) indica que não cabe ao judiciário criar o direito, mas tão somente aplicá-lo), Maus, por exemplo, parece se prender de maneira muito estrita e rigorosa no desenho montesquiano e fazer pouca conta para o fato de que o próprio Montesquieu previa uma série de moderações e controles sobre a jurisdição (fora a proibição de criar o direito), tais como o recrutamento sazonal de

11 "A Constituição importa porque ela fornece a estrutura de nossa política. É a política, não "a Constituição", que é a última - algumas vezes a imediata - fonte para qualquer proteção que nós temos para nossos direitos fundamentais" (tradução nossa). 
juízes do seio do povo, para se evitar o arbítrio pessoal de juízes de carreira. É certo que Montesquieu escreveu que "[t]ampouco existe liberdade se o poder de julgar não for separado do poder legislativo e do executivo", pois "[s]e estivesse unido ao poder legislativo, o poder sobre a vida e a liberdade dos cidadãos seria arbitrário [...]" (2000, p. 168), já que o juiz seria também legislador. No entanto, e mesmo por tais motivos, se em Montesquieu a soberania se divide entre o Legislativo e o Executivo, não há nada que impeça, em termos teóricos, que ela também seja dividida com o Judiciário - basta pensarmos em instrumentos e controles de moderação, sendo o principal, para se impedir o temor de termos em uma única figura o juiz e o legislador, a contestação da ideia de que o judiciário teria a "última palavra" acerca da interpretação constitucional, o que encerra também a contestação das ideias correntes acerca da supremacia da Constituição e, particularmente, do Judiciário como o guardião da Constituição.

De fato, nas atuais democracias não há como sustentar que algum poder teria a "última palavra". A rigor, conforme as teorias dos 'diálogos institucionais'12, a interpretação constitucional nunca tem fim, mas ocorre em ciclos que se reiniciam indefinidamente (GODOY, 2017; KOZICKI; ARAÚJO, 2015). Uma decisão judicial que desafia o legislativo, por exemplo, provoca a reação desse poder, o qual "responde" com novas propostas legislativas (seja rechaçando, concordando ou aprimorando a interpretação jurisdicional), "dialogando" com o judiciário, com os demais poderes e também com a sociedade. Este é o modelo dos movimentos pendulares do judicial review, ora fraco (weak) ora forte (strong) descrito por Tushnet $(2008)^{13}$, a depender do grau de consenso político e social (movimento análogo à construção de hegemonias, como descrito por Laclau e Mouffe) e da complexidade em torno das prestações de um direito fundamental. As cortes exercem um modelo forte quando há um consenso político sobre as obrigações que envolvem os direitos e/ou quando essas mesmas obrigações demonstram um menor grau de complexidade para serem entregues. Quando faltam consensos políticos e/ou as obrigações e prestações dos direitos são deveras complexas, as cortes preferem exercer um controle fraco, sem entrar em rota de colisão com o legislativo ou o executivo, adiando ou evitando decisões peremptórias ou transferido tais decisões para os demais poderes ou com esses compartilhando os ônus decisórios.

${ }^{12}$ Cf. tb. CLÈVE; LORENZETO, 2015, GODOY, 2017, MENDES, 2008, KOZICKI; ARAÚJO, 2015.

${ }^{13}$ Há certo diálogo mesmo em modelos fortes de controle constitucionalidade, como os do Brasil e dos EUA, nos quais se teria uma "última palavra provisória" por parte das cortes constitucionais (KOZICKI; ARAÚJO, 2015, p. 126). 
A ciência política empírica contemporânea (MENDES, 2008, p. 182-3) destaca que as cortes atuam politicamente todo o tempo, fazendo-o da seguinte forma: 1) ao testarem continuamente a reação dos demais poderes e da sociedade às suas decisões; 2) ao compreenderem a flexibilidade concreta da separação dos poderes; 3) ao verificarem a oscilação da legitimidade de cada participante dessa interação e a variação das correlações de força.

A título de exemplo, poderíamos lembrar dos debates públicos acerca dos temas da infidelidade partidária - cujas decisões por parte do STF (nos mandados de segurança ns. 26.602, 26.603 e 26.604 e nas ADIs ns. 3.999 e 4.086) seriam um judicial review forte, porquanto era um tema sem resistências políticas bem estabelecidas - , e da recepção constitucional ou não da Lei de Anistia, - sendo a posição da Suprema corte (na ADPF n. 153) um judicial review fraco, considerando o caráter altamente polêmico da questão, particularmente em vista da influência nunca olvidável de setores conservadores e das forças armadas (KOZICKI; ARAÚJO, 2015). Em outras palavras, para além da reticência do Supremo, ao não entrar "em bolas divididas", o que esses exemplos revelam, apesar dos limites institucionais da Constituição de 1988, é a existência de um diálogo entre o judiciário e os demais os poderes e a sociedade no Brasil - um diálogo velado e palaciano, é verdade, ainda sujeito a uma maior análise e transparência, mas, sem dúvida alguma, existente ${ }^{14}$.

Mesmo aderindo em parte à ideia rawlsiana e dworkiana da importante função das cortes na discussão de questões de princípio (de legitimidade substantiva, portanto) (MENDES, 2008, p. 194-208), bem como à concepção de se visualizar a Constituição como um documento representativo do "povo perpétuo", o qual deve estar a salvo das maiorias de ocasião ("povo atual”) (BURGOS; VIANNA, 2002, p. 362) ${ }^{15}$, o déficit democrático do Poder Judiciário no Brasil não nos permite dispensar uma profunda revisão de seus procedimentos decisórios. Em outros termos, mesmo que não se ignore que a legitimidade tenha adquirido um sentido 'reflexivo', passando a ser definida também "pela qualidade da sua expressão junto à sociedade" (SOMBRA, 2017, p. 240) ${ }^{16}$, não há como ignorar a necessidade de o Poder Judiciário ampliar sua legitimidade democrática nos sentidos de se aperfeiçoar o

\footnotetext{
${ }^{14}$ Algo parecido ocorre com a percepção acerca da prática do lobby.

${ }^{15}$ Sem se olvidar das pertinentes críticas ao elitismo da tradição do constitucionalismo estadunidense, conforme apontado por Bercovici (2013).

16 Neste sentido reflexivo, Sombra (2017, p. 239) escreve sobre a importância crescente para o conceito contemporâneo de legitimidade democrática dos fatores de accountability e de responsividade.
} 
compartilhamento das consequências políticas de suas decisões com a sociedade (agir com o outro) e a capacidade de os indivíduos intervirem decisivamente na tomada de suas decisões (capacidade de influência) (SOMBRA, 2017, p. 238).

Daí que, neste ponto algumas coisas se revelam mais claras: 1) evidentemente, como sustentado ao final acima, devem existir constrangimentos e limites para o exercício político do judiciário, os quais necessitam ser de várias sortes: normativos (Constituição, leis), hermenêutico-racionais, político-institucionais, culturais etc. Não que esses limites sejam infalíveis (nada o é), mas devem ser minimamente compartilhados pela comunidade de intérpretes, a fim de se garantir a autonomia e a racionalidade do direito; 2) que a maior garantia de o judiciário se manter dentro desses limites é o funcionamento saudável e efetivo da própria democracia - que o próprio judiciário deve endossar e arbitrar - e na qual sejam permitidas a veiculação de demandas de formas vertical e horizontal, a construção de novas posições intersubjetivas e de novos direitos e a disputa não violenta entre forças políticas diversas, evitando-se o lawfare ou o uso frequente de todos os instrumentais jurídicos à disposição (ou seja, a necessidade de desjuridificarmos relativamente a democracia); na qual os atores políticos, em um ambiente democrático minimamente equânime, compreendam o papel da Constituição (qual seja, não o de proteger diretamente os direitos, mas sim a política), cobrando diuturnamente o respeito ao ordenamento jurídico (SANTOS, 2018, p. 42); 3) por fim, e não menos importante, a necessidade de novos desenhos e constrangimentos institucionais internos e externos ao Poder Judiciário (novos mecanismos de controle e participação democráticos nas decisões judiciais e nas estruturas de poder), permitindo-se que este possa fazer política, mas à luz de um vigoroso escrutínio e diálogo públicos.

Apesar de não ser o escopo do presente texto, podemos esboçar alguns caminhos para novos desenhos e constrangimentos institucionais ao Poder Judiciário, os quais devem aperfeiçoar os vários sentidos da legitimidade citados acima (reflexividade, agir com o outro e capacidade de influência): ampliação do colégio de eleitores (hoje formado apenas por desembargadores) para as eleições dos presidentes de tribunais de justiça dos estados e para os tribunais regionais federais; alteração na forma de recrutamento dos juízes, com a valorização de disciplinas não jurídicas e da cultura da pesquisa científica e acadêmica; a conferência de maior peso à argumentação entre os atores processuais, particularmente prescrevendo a necessidade de os colegiados produzirem suas decisões através de um único voto vencedor, criando-se maior unidade jurisprudencial; novas regulamentações legais sobre prazos e ordens 
de julgamento nas cortes, a fim de evitar a manipulação das pautas, os atrasos propositais para a entrega de relatórios e votos, os pedidos de vista eternos etc. (KOZICKI; ARAÚJO, 2015, p. 117-9; RODRIGUEZ, 2013, p. 111, p. 152); aperfeiçoamento dos institutos de amicus curiae e de audiências públicas; quanto às audiências públicas: que elas possam ser requeridas ou convocadas também pelas partes e pela sociedade; que nelas seja exigida a participação de todos os juízes da respectiva corte julgadora; que seus critérios de inscrição para participação sejam transparentes e normativamente prescritos (KOZICKI; ARAÚJO, 2015, p. 119-120; SOMBRA, 2017); possibilidade da participação popular, por meio de conferências, na construção dos planejamentos estratégicos dos tribunais; ouvidorias externas; criação de novos e mais precisos indicadores de resultados, de qualidade e de satisfação dos cidadãos com relação aos serviços jurisdicionais.

Em uma palavra: é possível uma democracia funcionar razoavelmente bem sem a necessidade da atuação constante do judiciário e, particularmente, dos tribunais constitucionais, mas funcionar bem com um judiciário ou uma corte constitucional ignorando a política democrática é absolutamente impossível ${ }^{17}$.

\section{Conclusão}

O presente artigo teve como principal objetivo repensar o estágio atual da democracia diante do fenômeno dual de judicialização da política e do ativismo judicial.

Percebeu-se que os consensos nas esferas do direito e da política, as quais se entrelaçam continuamente e dependem de construções de subjetividades e de posições hegemônicas, são sempre provisórios e necessitam da abertura à oposição que os contesta. E é exatamente aí que mora a força da a democracia-liberal, da impossibilidade de reconciliação final entre os valores liberais (liberdade) e democráticos (igualdade), uma vez que é impossível aos dois, e ao mesmo tempo, realizarem-se por completo. Por isso que a aceitação (e não a negação) de tais paradoxos e do caráter inerentemente político da construção de consensos, mesmo os jurídicos, poderia permitir à atividade jurisdicional uma atuação mais legítima socialmente.

\footnotetext{
17 Aliás, parece que, até o presente momento, ainda não foram encontradas evidências empíricas suficientes confirmando a tese (hoje hegemônica) de que o grau de respeito aos direitos e liberdades individuais seria maior em democracias com tribunais constitucionais (SANTOS, 2018, p. 28-30; SHAPIRO, 2006, p. 282-4).
} 
Em seguida, refletiu-se como o debate em torno dos fenômenos da judicialização da política ou do ativismo judicial são mal formulados, pois caem no equívoco ingênuo de achar que o ato de interpretação judicial é um ato puramente técnico. Diante de tal quadro, mais importante do que respeitar o direito em um sentido eminentemente técnico, é respeitá-lo em um sentido político, no qual o apreço às regras do fazer político é muito mais fundamental para a construção de consensos e para a proteção dos direitos do que a adjudicação direta desses mesmos direitos pelo Poder Judiciário.

Por fim, com ajuda dos 'diálogos institucionais', desconstruiu-se também a ideia de que o judiciário teria a "última palavra" acerca da interpretação do direito, pois, em verdade, a interpretação constitucional e legal nunca tem fim, ocorrendo em ciclos que se reiniciam indefinidamente, o que exige a submissão do Poder Judiciário a uma maior accountability democrática, tarefa premente e inadiável que se apresenta à sociedade brasileira atual.

\section{Referências Bibliográficas}

BARROS, Celso Rocha. “O Brasil e a recessão democrática. Como o cenário político global ajuda a entender a nossa crise - e vice-versa". Questões de poder II. Revista Piauí. Edição 139. Abril de 2018. Disponível em <http://piaui.folha.uol.com.br/materia/o-brasil-e-recessaodemocratica/\#>. Acesso em 10/04/2018.

BERCOVICI, Gilberto. "A Constituição invertida: a Suprema Corte Americana no combate à ampliação da democracia”. Lua Nova, São Paulo, n. 89, p. 107-134, 2013. Disponível em <http://www.scielo.br/scielo.php?script=sci_arttext\&pid=S0102-

64452013000200005\&lng=en\&nrm=iso> . Acesso em 10/05/2018.

BURGOS, Marcelo; VIANNA, Luiz Werneck. "Revolução Processual do Direito e Democracia Progressiva". In: VIANNA, Luiz Werneck (org.). A Democracia e os Três Poderes no Brasil. Belo Horizonte: Editora UFMG, Rio de Janeiro: IUPERJ/FAPERJ, 2002, p. 337-491. CARMARGO, Margarida Maria Lacombe; VIEIRA, José Ribas. “A estratégia institucional do juiz Sergio Moro descrita por ele mesmo. Quando flexibiliza garantias constitucionais, juiz se aproxima da concepção de Estado de Exceção”. Jota, 28 de Março de 2016. Disponível em $<$ https://jota.info/artigos/estrategia-institucional-juiz-sergio-moro-descrita-por-ele-mesmo28032016>. Acesso em 20/04/2016. 
CLÈVE, Clèmerson Merlin; LORENZETO, Bruno Meneses. "Diálogos institucionais: estrutura e legitimidade". Revista de Investigações Constitucionais. Núcleo de Investigações Constitucionais da UFPR. ISSN 2359-5639, Periodicidade quadrimestral, vol. 2, n. 3, Curitiba, setembro/dezembro, 2015.

DOUZINAS, Costas. O fim dos Direitos Humanos. Tradutora Luzia Araújo. Coleção Díke. São Leopoldo: Editora UNISINOS, 2009.

GODOY, Miguel Gulano de. Devolver a constituição ao povo: crítica à supremacia judicial e diálogos institucionais. Belo Horizonte: Fórum, 2017.

GOUVÊA, Marco Maselli. O controle judicial das omissões administrativas: novas perspectivas de implementação dos direitos prestacionais. Forense: Rio de Janeiro, 2003.

GRAY, John. Liberalism. 2nd ed. (Concepts in social thought). Minneapolis: University of Minnesota Press, 1995.

HOBSBAWM, Eric J. A Era dos Impérios, 1875-1914. Tradução de Sieni Maria Campos e Yolanda Steidel de Toledo. 7. ed. Rio de Janeiro: Paz e Terra. 2002.

LACLAU, Ernesto; MOUFFE, Chantal. Hegemony and Socialist Strategy - Towards a Radical Democratic Politics. Second Edition. Printed in US by Maple Press. London and New York: Verso, 2014.

LATOUR, Bruno. Jamais fomos modernos. Ensaio de Antropologia Simétrica. Tradução de Carlos Irineu da Costa. Editora 34: Rio de Janeiro, 1994.

LYNCH, Christian Edward Cyril. Da monarquia à oligarquia. História institucional e pensamento político brasileiro (1822-1930). 1. ed. São Paulo: Alameda, 2014.

KANT, Immanuel. Crítica da Razão Pura. Tradução de Manuela Pinto dos Santos e Alexandre Fradique Morujão. Introdução e Notas de Alexandre Fradique Morujão. 2a. ed., Lisboa: Fundação Calouste Gulbenkian, 1989.

KOZICKI, Katya; ARAÚJO, Eduardo Borges. "Um Contraponto Fraco a um Modelo Forte: o Supremo Tribunal Federal, a última palavra e o diálogo". Sequência (Florianópolis) [online]. 2015, n.71, pp.107-132. ISSN 0101-9562. Disponível em: <http://www.scielo.br/pdf/seq/n71/2177-7055-seq-71-00107.pdf>. Acesso em 02/04/2018. MATTEUCCI, Nicola. "Liberalismo". In: BOBBIO, Norberto; MATTEUCCI, Nicola; PASQUINO, Gianfranco. Dicionário de Política. V. 2. 5a. Edição - Brasília: Editora da Universidade de Brasília: São Paulo: Imprensa Oficial do Estado de São Paulo, 2004, p. 686705. 
MAUS, Ingeborg. Judiciário como superego da sociedade. Rio de Janeiro: Lumen Juris, 2010. MENDES, Conrado Hübner. Direitos Fundamentais, separação dos poderes e deliberação. Tese de Doutorado apresentada ao Departamento de Ciência Política da FFLCH-USP, 03 de julho de 2008. Disponível em <http://www.teses.usp.br/teses/disponiveis/8/8131/tde-05122008162952/pt-br.php>. Acesso em 02/04/2018.

MONTESQUIEU, Charles de Secondat. Baron de. O espírito das leis. São Paulo: Martins Fontes, 2000.

MORO, Sergio Fernando. "Considerações sobre a Operação Mani Pulite”. Revista CEJ. Brasília, n. 26, p. 56-62, jul./set. 2004. Disponível em <http://www.cjf.jus.br/ojs2/index.php/revcej/article/view/625/805>. Acesso em 05/05/2016.

MOUFFE, Chantal. O Regresso do Político. Tradução de Ana Cecília Simões, Revisão Técnica de José Soares de Almeida, Lisboa: Gradiva Publicações, 1996.

Democratic Paradox. London, New York: Verso, 2009.

RODRIGUES, Daniel dos Santos. A Defesa Judicial dos Direitos Sociais Prestacionais a partir da Teoria dos Direitos Humanos de Amartya Sen. A\&C Revista de Direito Administrativo e Constitucional. Ano 8, n. 34, outubro/dezembro 2008. Belo Horizonte: Fórum, 2008.

Direitos Humanos e Democracia à Luz das Críticas ao Liberalismo de Carl Schmitt e de Chantal Mouffe. Dissertação (mestrado). Trabalho não publicado. Universidade Federal de Goiás, Pró-reitoria de Pós-graduação (PRPG), Programa de Pós-Graduação em Direitos Humanos, Goiânia, 24 de novembro de 2014. Disponível em <https://repositorio.bc.ufg.br/tede/handle/tede/7760>. Acesso em 30/05/2018.

RODRIGUEZ, José Rodrigo. Como decidem as cortes? Para uma crítica do direito (brasileiro). - Rio de Janeiro: Editora FGV, 2013.

SANTOS, Pedro Felipe de Oliveira. "O futuro da jurisdição constitucional: as aspirações do constitucionalismo global no paradigma do engajamento comparativo". Revista do Tribunal Regional Federal da $1^{\text {a }}$ Região, v. 30 n. 1/2, janeiro/fevereiro 2018, Brasília, p. 23-44.

SCHMITT, Carl. Political Romanticism. Translated by Guy Oakes. Cambridge, Massachusetts and London, England: The MIT Press, 1986.

A situação intelectual do sistema parlamentar atual. In: A Crise da Democracia Parlamentar. Tradução de Inês Lohbauer, Coleção Clássica, São Paulo: Scritta, 1996. 
. Catolicismo Romano e Forma Política. Prefácio, tradução e notas de Alexandre Franco de Sá. Lisboa: Hugin Editores, 1998.

. The Concept of the Political. Expanded Edition, Kindle Edition. Translation, introduction, and notes by George Schwab, Chicago: The University of Chicago Press, 2007. SHAPIRO, Ian. Os fundamentos morais da política. Tradução Fernando Santos. Revisão da tradução Evandro Ferreira e Silva. São Paulo: Martins Fontes, 2006.

SOMBRA, Thiago Luís Santos. "Supremo Tribunal Federal representativo? O impacto das audiências públicas na deliberação”. Rev. direito GV. São Paulo, v. 13, n. 1, p. 236-273, abril 2017. Disponível em <http://www.scielo.br/scielo.php?script=sci_arttext\&pid=S1808$24322017000100236 \& \operatorname{lng}=$ en\&nrm=iso $>$. Acesso em 04/05/2018.

SOUZA, Jessé Jose Freire. A tolice da inteligência brasileira: ou como o país se deixa manipular pela elite. São Paulo: LeYa, 2015.

TUSHNET, Mark. Weak Courts, strong rights: judicial review and social welfare rights constitutional law. Kindle Edition. Princeton: Princeton University Press, 2008.

Why the constitution matters. New Haven: Yale University Press, 2010. 